
\title{
Reseracth Sulure \\ Modelling the effect of lockdown on COVID-19 pandemic in 22 countries and cities
}

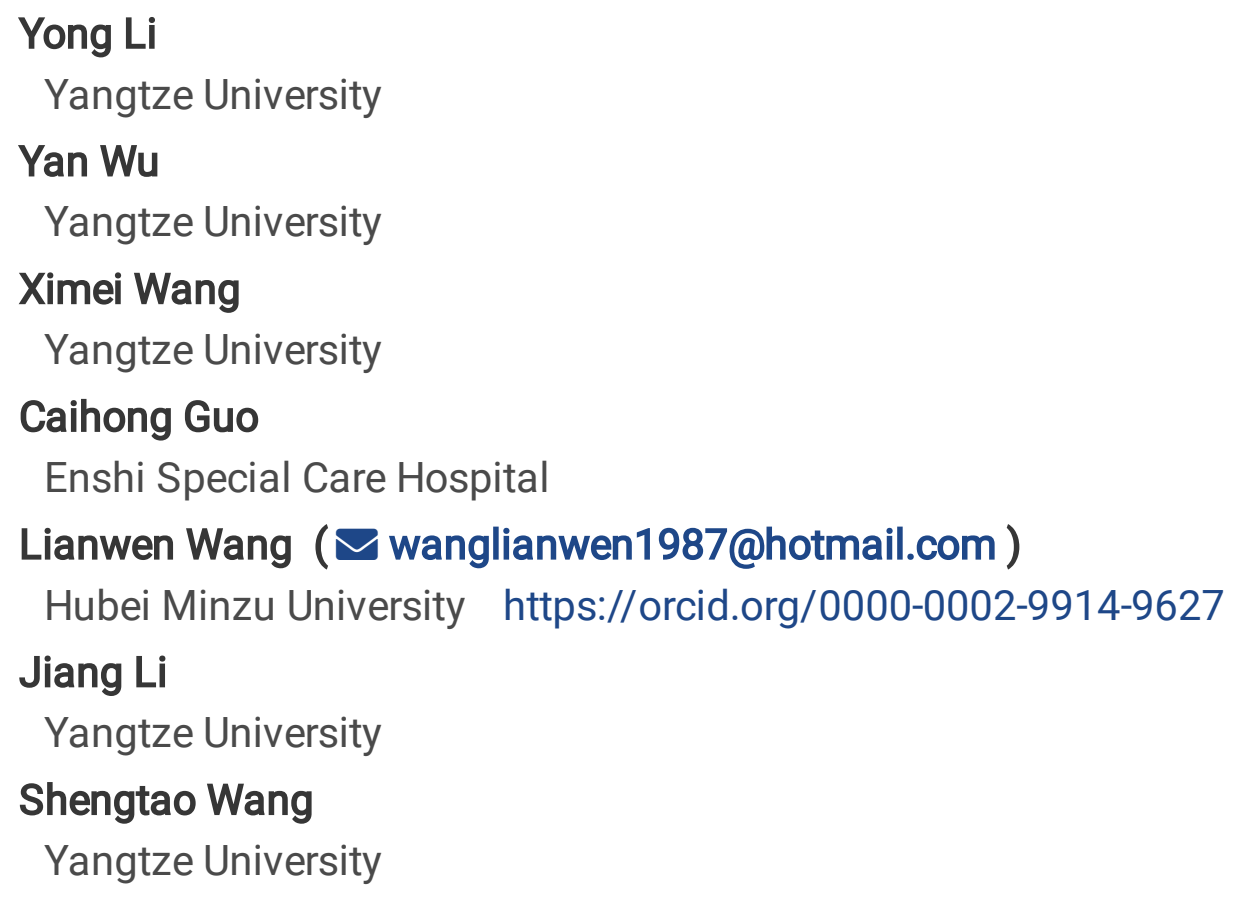

Research article

Keywords: COVID-19; Lockdown; SEIQR model; Basic reproduction number

Posted Date: June 8th, 2020

DOI: https://doi.org/10.21203/rs.3.rs-32891/v1

License: (c) (i) This work is licensed under a Creative Commons Attribution 4.0 International License.

Read Full License 


\title{
Modelling the effect of lockdown on COVID-19 pandemic \\ in 22 countries and cities
}

\author{
Yong $\mathrm{Li}^{1}$, Yan $\mathrm{Wu}^{1}$, Ximei Wang ${ }^{1}$, Caihong $\mathrm{Guo}^{2}$, Lianwen $\mathrm{Wang}^{3}$, Jiang $\mathrm{Li}^{1}$, Shengtao Wang ${ }^{1}$ \\ *Corresponding author: wanglianwen1987@hotmail.com \\ 1 School of Information and Mathematics, Yangtze University, Jingzhou, 434000, P.R.China \\ 2 Enshi Special Care Hospital, Enshi, 445000, P.R.China \\ 3 School of Mathematics and Statistics, Hubei Minzu University, Enshi, 445000, P.R.China
}

\begin{abstract}
Backgrounds: COVID-19 is currently spreading around the world, and the cumulative number of cases worldwide exceeded 5 million on 23 May 2020 (10:00 GMT+2). At present, many countries or cities have implemented lockdown measures. This study evaluated the inhibitory effect of lockdown measures on the pandemic by the use of lockdown or similar lockdown in 22 countries or cities.
\end{abstract}

Methods: An SEIQR epidemiological model was developed to capture the transmission dynamics of COVID-19. With the data related to COVID-19 from 22 countries or cities, the optimal parameters of the model were estimated, respectively.

Results: The average basic reproduction numbers of 22 countries or cities were between 1.5286-3.8067. And Russia Federation, Spain, Italy, France, Germany, the United Kingdom, Singapore, the United States of New York and the United States of New Jersey were hardest hit by COVID-19.

Conclusion: Although the pandemic has not been fundamentally controlled for a short time after lockdown, lockdown was proved to be an extremely effective control measure, which significantly scaled the number of patients down, thereby reduced the harmfulness of the 
pandemic.

Keywords: COVID-19; Lockdown; SEIQR model; Basic reproduction number

\section{Introduction}

Coronavirus disease (COVID-19) is a unusual coronavirus with strong infectiousness and high mortality [1]. Wuhan Municipal Health Commission, China, reported a cluster of cases of pneumonia in Wuhan, Hubei Province in December 2019. Gradually, more and more people fall ill who have the same symptom in other countries. The COVID-19 pandemic has been lasting around 5 months all around the world. There were 5,488,825 confirmed cases and the 349,095 deaths across the planet on 27 May 2020 according to the WHO (10:00 GMT+2) [2]. This epidemic is attacking 215 countries and regions around the world, such as USA, Spain, Italy, the United Kingdom, Russian Federation, Germany, Brazil, France, Turkey, Iran, Canada, Peru, India, Belgium, Netherlands, Republic of Korea and so on.

people of all ages are susceptible to the novel coronavirus infection $[3,4]$. Generally, after up to 14-day incubation period [5], most infectious individuals display mild symptoms [6] associated with respiratory illness [5] such as fever, dry cough, fatigue and productive cough, headache, diarrhea, myalgia [6-11], while about $16 \%$ of infectious individuals may develop severe symptoms including shortness of breath, chest pain [12]. The case fatality rate was $3.7 \%$ worldwide [8], and no specific medicine takes effect until now $[13,14]$. The existing evidences suggest that the main transmission of COVID-19 route is via respiratory droplets in an unprotected state and contacting closely with the infected person [13]. Many studies [15-17] revealed that infected individuals in incubation period may be infectious, which greatly increases the difficulty of prevention and 
control.

To prevent the virus from spreading, the Chinese government put up the "lockdown" measure in Wuhan on 23 January 2020, which was a new approach curbing infectious diseases [3]. Other countries have followed suit. "Lockdown" means home quarantine, sealing off the city from all outside for the interruption of the disease transmission. So the schools and businesses are closed, the public should observe home quarantine, keep social distance, stop gathering together and even must insist on wear a mask when they go out for essential activities during the lockdown period $[4,5]$.

Many studies estimated the basic reproduction number in the early phase of COVID-19 outbreak [15-33]. Some results indicated that the basic reproduction number was greater than 3 , Tang et al. ( 6.47 (95\%CI: 5.71-7.23)) [15], Shen et al., ( 4.71 (95\%CI: 4.50-4.92)) [16] and Jia et al. (5.6870 inside Hubei, 6.0295 outside Hubei) [17], Zhao et al. (3.58 (95\%CI: 2.89-4.39)) [18], Imai (1.5-3.5) [19], Read et al. ( 3.11 (95\%CI: 2.39-4.13)) [20], Cao (4.08) [21], Abbott et al. (2.8-3.8) [22], Bedfordet et al. (1.8-3.5) [23], Chen et al. (2.30 from reservoir to person and 3.58 from person to person) [24] and Huang et al. (3.04-4.35) [25]. More research results argued that the basic reproduction number was less than 3, such as Liu et al. ( 2.92 (95\%CI: 2.28-3.67)) [26], Li et al. (2.2 (95\%CI: 1.4-3.9)) [27], Riou (2.2) [28], Majumder et al. (2.55) [29], Tang et al. (1.48-1.69 in Xi'an) [30], Zhang et al. (2.28 (95\%CI: 2.06-2.52)) [31], Du et al. $1.32(95 \% \mathrm{CI}$ 1.16-1.48) [32] and so on. In fact, the basic reproduction number is closely related to time and region, thus depending on the severity of the epidemic.

In this contribution we developed an SEIQR (susceptible-exposed-infected but not hospitalized-infectious and isolated-recovered) epidemic model to capture the transmission 
dynamics of COVID-19. In details, based on the cumulative case data and permanent population data of 22 countries or cities, considering the time of lockdown and lifting the lockdown, and with the help of the global optimization algorithm, the parameters of the model were obtained, then the actual confirmed case data were fitted. Further, we considered the trend and scale of the epidemic if the countries or cities were not in lockdown. Our results showed that lockdown measures significantly reduced the number of confirmed cases. In 22 countries or cities, before the lockdown, the basic reproduction numbers were between 1.3884-4.1926; after the lockdown, the basic reproduction numbers were between 1.2141-3.7829; the average basic reproduction numbers were between 1.5286-3.8067. The number of basic reproduction numbers in all countries or cities had decreased sharply after lockdown. Although the epidemic has not been fundamentally controlled for a short time after lockdown in Russia Federation, Spain, Italy, France, Germany, the United Kingdom, Singapore, the United States of New York and the United States of New Jersey owing to their high severity of the epidemics, lockdown remains an extremely effective control strategy that significantly reduces the number of patients and the harmfulness of the pandemic.

\section{Methods}

\subsection{Data}

This study simulated the cumulative numbers of cases in 22 countries or cities, which were collected and sorted out from four official reports: (1) WHO (World Health Organization) [2] reports the total confirmed COVID-19 daily new cases worldwide, so the data of the 16 countries was available, including Australia, Belgium, Canada, Denmark, Egypt, France, Germany, India, Norway, Republic of Korea, Russian Federation, Singapore, South Africa, Spain, Switzerland and 
the United Kingdom. (2) The COVID Tracking Project [33] gave the confirmed COVID-19 daily in 56 states of the United States, and we collected the data of 4 cities of the United States, i.e., California, Illinois, New Jersey and New York. (3) The National Health Commission of the People's Republic of China (NHC) [34] releases daily reports on cumulative confirmed cases of COVID-19 (Nucleic acid test result is positive) of Wuhan City, Hubei Province every day. (4) The Department of Health of Italy [35] reports the daily total case number. The data of Wuhan city that we select isn't over until 1 March $2020(24: 00 \mathrm{GMT}+8)$ while the data of other countries and cities isn't over until 19 April 2020 (10:00 GMT+2). The population data of 22 countries or cities researched above are from World Population in 2020 [36] .

Lockdown suppressed the epidemic in the countries with serious epidemics. As we all know, Wuhan, China is the first city to adopt the strict lockdown measures, followed by other cities in China. It was worth mentioning that South Korea adopted a similar lockdown approach, although South Korea failed to implement strict measures to lockdown the city, such as Daegu and Gyeongsangbuk-do, which were seriously affected by the epidemic. The time of lockdown, time of remove the lockdown and the specific measures of lockdown in 22 countries or cities were listed in Supplementary Materials (see Table 3 for details).

\subsection{The COVID-19 Model}

In what follows, the impact of lockdown on the COVID-19 epidemics in the 22 countries or cities was investigated by formulating an SEIQR epidemic model. The total population related to COVID-19, $N$, was divided into 5 epidemiological subgroups: susceptible, $S$; exposed, $E$; infectious but not hospitalized (maybe quarantine at home), $I$; infectious and isolated $Q$ and 
recovered, $R$ individuals, thus $N=S+E+I+Q+R$. Meanwhile, " $M$ " represents the number of the cumulative infectious and isolated individuals, $" C$ " denotes the number of the individuals who are identified not to be patients with COVID-19 and removed from the system. Note that the suspected cases during the COVID-19 pandemic may be influenza patients from current influenza season since their symptoms are similar to those of COVID-19 patients. Consequently, the following modelling assumptions were made based on some biological significance:

(1) Natural birth and death were ignored since we focused on the short-term transmission dynamics;

(2) The individuals in incubation period have the potential to transmit the virus. In addition, infectious and quarantined individuals $Q$ still also have a certain probability to transmit the virus to medical workers. Therefore, the exposed $(E)$ and the infectious and quarantined $(Q)$ were considered infectious, with infectivity reduction factors $p$ and $q$, respectively;

(4) It was assumed that the transmission rate $(\beta)$ will decrease and the proportion of confirmed cases $(1-\rho)$ will increase after the lockdown. It was realistic to suppose that more people stay in a safer isolation place on the lockdown day, resulting in a decrease in the number of susceptible people.

These considerations above yielded the schematic flow diagram illustrating the transmission dynamics of the COVID-19 in Fig 1, and then the model was described by the following system of ordinary differential equations: 


$$
\left\{\begin{array}{l}
\frac{d S}{d t}=-\frac{\beta_{1} S(p E+I+q Q)}{N} \\
\frac{d E}{d t}=\frac{\beta_{1} S(p E+I+q Q)}{N}-\alpha E, \\
\frac{d I}{d t}=\alpha \rho E-(\omega+\sigma) I, \\
\frac{d Q}{d t}=\alpha(1-\rho) E+\omega I-(\gamma+d) Q, \\
\frac{d R}{d t}=\gamma Q, \\
\frac{d M}{d t}=\alpha(1-\rho) E+\omega I .
\end{array}\right.
$$

The biological meanings and acceptable ranges of all parameters of model (1) were demonstrated in Table 1. The basic reproduction number $\left(R_{0}\right)$ represents the number of infected during the initial patient's infectious (not sick) period. This threshold value may determine whether a disease will die out (if $R_{0}<1$ ) or become epidemic (if $R_{0}>1$ ). As far as the epidemic models with complex dynamics, $R_{0}<1$ is not only the condition guaranteeing that the disease is extinct, but also the smaller the better. Following Van den Driessche and Watmough [37], we computed the basic reproduction number by COVID-19 as $R_{0}$, where

$$
\begin{aligned}
R_{0}= & \underbrace{\frac{\beta_{1} p}{\alpha}}_{\text {contact with exposed class }}+\underbrace{\frac{\beta_{1} \rho}{\omega+\sigma}}_{\text {contact with infected class }}+\underbrace{\frac{\beta_{1} q(\rho \omega+(\omega+\sigma)(1-\rho))}{(\omega+\sigma)(\gamma+d)}}_{\text {contact with quarantined class }} \\
& :=R_{01}+R_{02}+R_{03} .
\end{aligned}
$$

Here, $R_{01}, R_{02}$ and $R_{03}$ represent the average numbers of the infected individuals by a single exposed individual $E$, infectious but not hospitalized individual $I$ or infectious and quarantined individual $Q$ in a fully susceptible population, respectively. This also suggests that three transmission ways of COVID-19 contribute to the basic reproduction number $R_{0}$.

\section{Parameter Estimation}

The average incubation period ( $1 / \alpha)$ of COVID-19 is 5.1 days [4], so transition rate of 
exposed individuals $E$ read $\alpha=0.1961$. We consulted the values of $p=0.1$ and $q=0.38$ by Chowell et al. [38], disease-induced death rate $d=1.7826 \times 10^{-5}$ from Tang et al. [15], then the appropriate range of $p, q$, and $d$ could be obtained. Considering that the disease course $(1 / \delta)$ is more than 10 days, and the time requiring to detect a suspected patient $(1 / \omega)$ is 5 to 15 days, we thus determined the ranges of parameters $\delta$ and $\gamma$, respectively. The lower and upper limits of other parameters and initial values of model (1) were shown in Table 1. By application of model (1), we fitted the numbers of the cumulative confirmed cases $(M(t))$ to estimate the parameters and initial values through calculating the objective function as follows $[39,40]$

$$
\min \sum \frac{\left(M\left(t_{i}\right)-\hat{M}\left(t_{i}\right)\right)^{2}}{\hat{M}\left(t_{i}\right)}
$$

with the MATLAB (the Mathworks, Inc.) global optimization tool GlobalSearch. Here, $M\left(t_{i}\right)$

represent the numbers of the cumulative confirmed cases on day $i . \hat{M}\left(t_{i}\right)$ stand for the corresponding fitting values. The simulated parameter values for the 22 countries and cities were shown in Supplementary Materials (Table 4).

\section{Results and Discussion}

Fig. 2 (a)-(v) shows the fitting results of the 22 countries or cities after lockdown. Meanwhile, the trends of the cumulative number of confirmed cases without lockdown measures were also demonstrated. Judging from the results, lockdown measures in almost countries or cities dramatically reduced the number of confirmed cases, in addition to that Singapore's lockdown measures had no obvious effect on the epidemic control (Fig. 2 (r)). Accordingly, this revealed that a series of strict lockdown measures, for example, locking down cities, restrict access control, suspension from school, home quarantine, canceling social gathering activities, etc., indeed brought about a positive effect on the control of the COVID-19 epidemics. 
Based on the simulated parameters, we calculated the basic reproduction numbers before lockdown $\left(R_{0}^{(1)}\right)$ and after lockdown $\left(R_{0}^{(2)}\right)$ for the 22 countries and cities. Supposed that $t_{1}$ was the number of confirmed cases on the first day when the simulation started in a certain country (or city), and $t_{*}$ was the time of the lockdown. Then the basic reproduction number in the average sense could be defined as $\bar{R}_{0}=\frac{R_{0}^{(1)} \times\left(t_{*}-t_{1}\right)+R_{0}^{(2)} \times\left(t_{N}-t_{*}+1\right)}{t_{N}-t_{1}+1}$. Detailed results could be found in the second, third and fourth columns of Table 2.

At the same time, we defined the growth ratio of cumulative confirmed cases before the lockdown, $\Delta_{j}=\frac{M\left(t_{*}^{j}-1\right)-M\left(t_{*}^{j}-5\right)}{M\left(t_{*}^{j}-5\right)}$, where $M\left(t_{*}{ }^{j}-1\right), M\left(t_{*}{ }^{j}-5\right)$ indicated the cumulative number of confirmed cases on the day before locking down the country (or city) $j$ and on the fourth day before locking down the country (or city) $j$, respectively. Detailed results were listed in the last column of Table 2.

In the 22 countries or cities, before the lockdown, the basic reproduction numbers were between 1.3884-4.1926; after the lockdown, the basic reproduction numbers were between 1.2141-3.7829; the average basic reproduction numbers were between 1.5286-3.8067. The results were in good agreement with many existing results [18-32]. The basic reproduction numbers in the 22 countries or cities decreased significantly after the lockdown, which suggested that lockdown measures indeed suppressed the epidemics. The basic reproduction numbers after the lockdown were greater than 1 , so the epidemic were not fundamentally controlled for a short time after the lockdown (except for Wuhan until 1 March 2020 and other countries or cities until 19 April 2020). At the same time, we also calculated the growth ratio of confirmed cases in the five days before lockdown. This value intuitively reflects the increase rate in cases before the 
lockdown. Judging from the values of basic reproduction numbers, Russia Federation, Spain, Italy, France, Germany, the United Kingdom, Singapore, New York and New Jersey were very severely affected areas. This conclusion was also consistent with the case data reported by WHO [2]. Combining basic reproduction numbers, lockdown time and case growth ratio, Denmark, Egypt and Singapore adopted lockdown measures earlier when the outbreaks were relatively less severe.

\section{Conclusion}

According to the epidemiological characteristics of COVID-19, an SEIQR model was established. Considering the lockdown time and the number of confirmed cases in 22 countries or cities, we simulated the epidemiological parameters of each country or city, and made a detailed comparative analysis on whether to implement the lockdown measures (as shown in Fig. 2). A significant reduction in basic reproduction number (as shown in Table 2) and the number of cases reported by 22 countries or cities is significantly lower than that without lockdown measures (Fig.

2) show that lockdown is an extremely effective control measure.

Currently, COVID-19 still has been rampant around the world, threatening people's health and affecting people's normal lives. Many countries and territories have been carrying out strict measures to lock down the cities and even country. Obviously, timely lockdown could limit the epidemics to the smaller areas and avoid large-scale outbreaks, and thus lockdown is such an extremely effective control measure that can significantly reduce the number of patients and the harmfulness of the epidemic. In the face of the persistent spread of the epidemic, it is necessary for us to consider the measures of lockdown the city in time, which also brings inspiration for similar sudden infectious diseases in the future. 


\begin{abstract}
Abbreviations
COVID-19: Novel coronavirus disease; WHO: World Health Organization; NHC: National Health Commission; GMT: Greenwich Mean Time; SEIQR: Susceptible-exposed-infected but not hospitalized-infectious and isolated-recovered;
\end{abstract}

\title{
Acknowledgments
}

We would like to thank anonymous reviewers for very helpful suggestions which improved greatly this manuscript.

Author Contributions: Conceptualization, Y.L. and L.W.; methodology, Y.L. and L.W.; software, Y.L. and Y.W.; validation, Y.L. and L.W.; formal analysis, Y.L. and L.W.; investigation, Y.L. and L.W.; resources, Y.L., C.G. and L.W.; data curation, Y.L., J.L., S.W. and X.W.; writing—original draft preparation, Y.L., X.W. and L.W.; writing—review and editing, Y.L. and L.W.; visualization, Y.L. and L.W.; supervision, L.W.; project administration, Y.L. and L.W.; funding acquisition, Y.L. and L.W. All authors have read and agreed to the published version of the manuscript.

\section{Funding}

The work was partially supported by the National Natural Science Foundation of China (No. 11901059), Natural Science Foundation of Hubei Province, China (No. 2019 CFB353 and 2019CFB241). The funding body had no role in the study design, collection, analysis, interpretation of data and in writing the manuscript.

\section{Availability of data and materials}


All data are publicly available.

\section{Ethics approval and consent to participate}

Since no individual patient's data was collected, the ethical approval or individual consent was not applicable.

\section{Consent for publication}

Not applicable.

\section{Competing interests}

The authors declare that there is no conflict of interests regarding the publication of this article. No authors have potential conflicts of interest with reference to this work.

\section{References}

[1] Li R, Pei S, Chen B, Song Y, Zhang T, Yang W, Shaman J. Substantial undocumented infection facilitates the rapid dissemination of novel coronavirus (SARS-CoV2). Science 2020, 368(6490), $489-493$.

[2] WHO. Coronavirus disease (COVID-2019) situation reports. Available online: https://www.who.int/emergencies/diseases/novel-coronavirus-2019/situation-reports (accessed on 25 May 2020).

[3] Mao L, Xu J, Xu Z, Xia X, Li B, He J, Zhao P, Pan J, Zhang D. et al. A child with household transmitted COVID-19. BMC Infect Dis 2020; 20: 329.

[4] Lauer SA, Grantz KH, Bi Q, Jones FK, Zheng Q, Meredith H R, Azman AS, Reich NG, Lessler J. The Incubation Period of Coronavirus Disease 2019 (COVID-19) From Publicly Reported Confirmed Cases: Estimation and Application. Ann Intern Med 2020; 172(9): 577-582.

[5] $\mathrm{Wu} \mathrm{JT}$, Leung K, Leung GM. Nowcasting and forecasting the potential domestic and international spread of the 2019-ncov outbreak originating in Wuhan, China: a modelling study. Lancet 2020; 10225: 689-697. 
[6] Zhang P, Cai Z, Wu W, Peng L, Li Y, Chen C, Chen L, Li J, Cao M. et al. The novel coronavirus (COVID-19) pneumonia with negative detection of viral ribonucleic acid from nasopharyngeal swabs: a case report. BMC Infect Dis 2020; 20: 317.

[7] Chan JF, Yuan S, Kok KH, To KK, Chu H, Yang J, Xing F, BNurs JL, Yip CC, Poon RW, et al. A familial cluster of pneumonia associated with the 2019 novel coronavirus indicating person-to-person transmission: a study of a family cluster. Lancet. 2020; 395(10223): 514-523.

[8] Zhao X, Xu X, Yin H, Hu Q, Xiong T, Tang Y, Yang A, Yu B, Huang Z. Clinical characteristics of patients with 2019 coronavirus disease in a non-Wuhan area of Hubei Province, China: a retrospective study. BMC Infect Dis 2020; 20: 311.

[9] Liu Q, Li D, Liu Z, Gao Z, Zhu J, Yang J, Wang Q. Assessing the tendency of 2019-nCoV (COVID-19) outbreak in China. medRxiv. 2020. https://doi.org/10.1101/2020.02.09.20021444

[10] Wang S, Kang B, Ma J, Zeng X. A deep learning algorithm using CT images to screen for corona virus disease (COVID-19). medRxiv. 2020. https://doi.org/10.1101/2020.02.14.20023028

[11] Zhou C. Evaluating new evidence in the early dynamics of the novel coronavirus COVID-19 outbreak in Wuhan, China with real time domestic traffic and potential asymptomatic transmissions. MedRxiv. 2020. https://doi.org/10.1101/2020.02.15.20023440

[12] Guan W, Liang W, Zhao Y, Liang H Chen Z, Li Y, Liu X, Chen R, Tang C, Wang T, et al. Comorbidity and its impact on 1,590 patients with COVID-19 in China: A nationwide analysis. Eur Respir J 2020; 55(5).

[13] Centers for disease control and prevention (CDC). Global COVID-19 pandemic notice. Available online: https://wwwnc.cdc.gov/travel/notices/warning/coronavirus-global (accessed on 20 April, 2020).

[14] Sun H, Qiu Y, Yan H, Huang Y, Zhu Y, Chen S, et al. Tracking and predicting COVID-19 epidemic in China mainland. MedRxiv. 2020. https://doi.org/10.1101/2020.02.17.20024257

[15] Tang B, Wang X, Li Q, Bragazzi NL, Tang S, Xiao Y, Wu J. Estimation of the transmission risk of the 2019-nCoV and its implication for public health interventions. J Clin Med 2020; 9(2): 462.

[16] Shen M, Peng Z, Xiao Y, Zhang L. Modelling the epidemic trend of the 2019 novel coronavirus outbreak in China. bioRxiv. 2020. https://doi.org/10.1101/2020.01.23.916726.

[17] Jia J, Ding J, Liu S, Liao G, Li J, Duan B, Wang G, Zhang R. Modeling the control of COVID-19: impact of policy interventions and meteorological factors. Electron J Differ Eq 2020.

[18] Zhao S, Lin Q, Ran J, Musa SS, Yang G, Wang W, Lou Y, Gao D, Yang L, He D, Wang MH. Preliminary estimation of the basic reproduction number of novel coronavirus (2019-nCoV) in China, from 2019 to 2020: A data-driven analysis in the early phase of the outbreak. Int J Infect Dis 2020; 92: 214-217.

[19] Imai N, Dorigatti I, Cori A, Donnelly C, Riley S, Ferguson NM. Report 2: Estimating the Potential Total Number of Novel Coronavirus Cases in Wuhan City, China. Available online: https://www.imperial.ac.uk/media/imperial-college/medicine/sph/ide/gida-fellowships/2019-nCoV outbreak-report-22-01-2020.pdf (accessed on 23 January 2020).

[20] Read JM, Bridgen JR, Cummings DA, Ho A, Jewell CP. Novel coronavirus 2019-nCoV: early estimation of epidemiological parameters and epidemic predictions. medRxiv. 2020. https://doi.org/10.1101/2020.01.23.20018549.

[21] Cao Z, Zhang Q, Lu X, Pfeiffer D, Jia Z, Song H, Zeng DD. Estimating the effective reproduction number of the 2019-nCoV in China. medRxiv.2020. 
https://doi.org/10.1101/2020.01.27.20018952.

[22] Abbott S, Hellewell J, Munday J, CMMID nCoV working group, Funk S. The transmissibility of novel coronavirus in the early stages of the 2019-20 outbreak in Wuhan: exploring initial point-source exposure sizes and durations using scenario analysis. Wellcome Open Res 2020; 5: 17.

[23] Bedford T, Neher R, Hadfield J, Hodcroft E, Ilcisin M, Müller N. Genomic analysis of nCoV spread. Situation report 2020-01-30. Available online:

https://nextstrain.org/narratives/ncov/sit-rep/en/2020-01-30. (accessed on 30 January 2020).

[24] Chen T, Rui J, Wang Q, Zhao Z, Cui J, Yin L. A mathematical model for simulating the phase-based transmissibility of a novel coronavirus. Infect Dis Poverty 2020; 9(1): 1-8.

[25] Huang S, Peng Z, Jin, Z. Studies of the strategies for controlling the COVID-19 epidemic in China: Estimation of control efficacy and suggestions for policy makers (in Chinese). Sci Sin Math 2020; 50: 1-14.

[26] Liu T, Hu J, Kang M, Lin L, Zhong H, Xiao J, et al. Transmission dynamics of 2019 novel coronavirus (2019-nCoV). bioRxiv. 2020. https://doi.org/10.1101/2020.01.25.919787.

[27] Li Q, Guan X, Wu P, Wang X, Zhou L, Tong Y, Ren R, Leung KSM, Lau EHY, Wong JY, et al. Early transmission dynamics inWuhan, China, of novel coronavirus-infected pneumonia. $N$. Engl. J. Med. 2020.

[28] Riou J, Althaus CL. Pattern of early human-to-human transmission of Wuhan 2019 novel coronavirus (2019-nCoV), December 2019 to January 2020. Euro Surveill 2020; 25(4).

[29] Majumder M, Mandl KD. Early transmissibility assessment of a novel coronavirus in Wuhan, China. Available at SSRN: http://dx.doi.org/10.2139/ssrn.3524675.

[30] Tang S, Tang B, Bragazzi NL, Xia F, Li T, He S, Ren P, Wang X, Peng Z, Xiao Y, et al. Stochastic discrete epidemic modeling of COVID-19 transmission in the Province of Shaanxi incorporating public health intervention and case importation. medRxiv. 2020. https://doi.org/10.1101/2020.02.25.20027615.

[31] Zhang S, Diao M, Yu W, Pei L, Lin Z, Chen D. Estimation of the reproductive number of novel coronavirus (COVID-19) and the probable outbreak size on the Diamond Princess cruise ship: A data-driven analysis. Int J Infect Dis 2020; 93: 201-204.

[32] Du Z, Xu X, Wu Y, Wang L, Cowling BJ, Meyers LA. Serial interval of COVID-19 among publicly reported confirmed cases. Emerg Infect Dis 2020; 26(6).

[33] The COVID Tracking Project. Data API. Available online: https://covidtracking.com/api (accessed on 20 April 2020).

[34] National Health Commission of the People's Republic of China. Outbreak Notification. Available online: http://www.nhc.gov.cn/xcs/yqtb/list_gzbd.shtml (accessed on 28 April 2020).

[35] Ministry of Health (in Italian). News of the area New coronavirus. Available online:

http://www.salute.gov.it/portale/nuovocoronavirus/archivioNotizieNuovoCoronavirus.jsp?lingua=i taliano $\&$ menu $=$ notizie $\& p=$ dalministero $\&$ area $=$ nuovocoronavirus $\&$ notizie. page $=0($ accessed on 28 April 2020).

[36] PopulationStat. World population. Available online: https://populationstat.com/ (accessed on 19 April 2020).

[37] Van den Driessche P, Watmough J. Reproduction numbers and sub-threshold endemic equilibria for compartmental models of disease transmission. Math Biosci 2002; 180(1-2): 29-48. 
[38] Chowell G, Fenimore PW, Castillo-Garsow MA, Castillo-Chavez C. SARS outbreaks in Ontario, Hong Kong and Singapore: the role of diagnosis and isolation as a control mechanism. J Theor Biol 2003; 224(2003): 1-8.

[39] Li Y, Wang L, Pang L, Liu S. The data fitting and optimal control of a hand, foot and mouth disease (HFMD) model with stage structure. Appl Math Comput 2016; 276: 61-74.

[40] Zhang X, Zhao Y, Neumann AU. Partial immunity and vaccination for influenza. J Comput Biol 2010; 17: 1689-1696.

[41] The Fiji Times. Australia starts lockdown measures as coronavirus cases jump. Available online:

https://www.fijitimes.com/australia-starts-lockdown-measures-as-coronavirus-cases-jump/ (accessed on 23 March 2020).

[42] Belgium.be. Coronavirus: reinforced measures. Available online:

https://www.belgium.be/en/news/2020/coronavirus_reinforced_measures (accessed on 24 March 2020).

[43] EURACTIV. Belgium extends COVID-19 lockdown by two weeks until 19 April. Available online:

https://www.euractiv.com/section/coronavirus/news/belgium-extends-covid-19-lockdown-by-twoweeks-until-19-april/ (accessed on 28 March 2020).

[44] Sacramento Bee.Sacramento County issues formal order for residents to stay at home as coronavirus spreads. Available online:

https://www.sacbee.com/news/coronavirus/article241332696.html (accessed on 19 March 2020).

[45] Wall Street Journal. California Orders Lockdown for State's 40 Million Residents. Available online:

https://www.wsj.com/articles/china-reports-no-new-domestic-coronavirus-infections-for-the-first-t ime-since-outbreak-started-11584611233 (accessed on 20 March 2020).

[46] CTV News. Canada restricting who can enter the country due to COVID-19: PM Trudeau. Available online:

https://www.ctvnews.ca/health/coronavirus/canada-shutting-the-border-to-most-non-citizens-due-t o-covid-19-pm-trudeau-1.4854503 (accessed on 16 March 2020).

[47] POLITIK.Get an overview of the new corona action: See what you shouldn't do today at 10am. Available online:

https://www.dr.dk/nyheder/politik/faa-overblikket-over-de-nye-corona-tiltag-se-hvad-du-ikke-maa -fra-i-dag-klokken-10 (accessed on 17 March 2020).

[48]BBC Arabic (in Arabic). Corona Virus: One death, 46 new infections in Egypt, and increasing infections in Arab countries. Available online: https://www.bbc.com/arabic/middleeast-51963726 (accessed on 19 March 2020).

[49] The Independent. France imposes 15-day lockdown and mobilises 100,000 police to enforce coronavirus restriction. Available online:

https://www.independent.co.uk/news/world/europe/coronavirus-france-lockdown-cases-update-co vid-19-macron-a9405136.html (accessed on 16 March, 2020).

[50] The Independent. Cuthbertson, Anthony . Coronavirus: France extends lockdown until 11 May. Available online:

https://www.independent.co.uk/news/world/europe/coronavirus-france-lockdown-macron-a94583 86.html (accessed on 13 April 2020). 
[51] spiegel.de. An Overview of the Updated Restrictions on Public Life in Germany. Available online:

https://www.spiegel.de/consent-a-?targetUrl=https\%3A\%2F\%2Fwww.spiegel.de\%2Finternational \%2Fgermany\%2Fgermany-imposes-tougher-restrictions-on-public-life-a-fe 5a067b-ee7a-4521-994 0-edfa637f90de\&ref=https\%3A\%2F\%2Fen.wikipedia.org\%2F (accessed on 25 April 2020).

[52] focus.de (in German). Kontaktbeschränkung, Masken, Einkaufen: Was jetzt in Ihrem Bundesland gilt. focus.de (in German). Available online:

https://www.focus.de/finanzen/recht/kontaktbeschraenkung-einkaufen-masken-was-gilt-jetzt-wasaendert-sich_id_11793149.html (accessed on 25 April 2020).

[53] Chicago Tribune. Gov. J.B. Pritzker issues order requiring residents to 'stay at home' starting Saturday. Available online:

https://www.chicagotribune.com/coronavirus/ct-coronavirus-illinois-shelter-in-place-lockdown-or der-20200320-teedakbfw5 gvdgmnaxlel54hau-story.html (accessed on 20 March 2020).

[54] NBC 5 Chicago. Illinois' Stay-at-Home Order Modified, Extended Through May, Pritzker Announces. Available online:

https://www.nbcchicago.com/news/coronavirus/pritzker-expected-to-extend-illinois-stay-at-homeorder-thursday-sources/2260588/ (accessed on 24 April 2020).

[55] China Daily. Indian PM Modi announces 21-day lockdown to fight COVID-1924 March 2020. Available online:

http://www.chinadaily.com.cn/a/202003/24/WS5e7a2114a310128217281b10.html (accessed on 24 March 2020).

[56] The Statesman. India extends lockdown till May 3; Global infections near two million.

Available online:

https://www.thestatesman.com/world/coronavirus-live-india-cases-cross-10000-mark-339-dead-fli ghts-trains-cancelled-may-3-1502877107.html (accessed on 14 April 2020).

[57] Roma Today (in Italiano). Coronavirus: stop a pub, cinema, teatro e discoteche anche a Roma. Ecco cosa prevede il nuovo decreto. Available online:

https://www.romatoday.it/attualita/coronavirus-pub-cinema-teatri-locali-chiusi-nuovo-decreto.html (accessed on 8 March 2020).

[58] Reuters. Italy extends coronavirus lockdown until May 3: Prime Minister. Available online: https://www.reuters.com/article/us-health-coronavirus-italy-conte/italy-extends-coronavirus-lockd own-until-may-3-prime-minister-idUSKCN21S1YL (accessed on 10 April 2020).

[59] nj.com. Coronavirus updates: Murphy orders residents to stay home as New Jersey reaches 1,327 cases, 16 deaths. Available online:

https://www.nj.com/coronavirus/2020/03/coronavirus-updates-murphy-orders-residents-to-stay-ho me-as-new-jersey-reaches-1327-cases-16-deaths.html (accessed on 21 March 2020).

[60] CNN. Cuomo orders all nonessential New York workers to stay home. Available online: https://edition.cnn.com/2020/03/20/politics/new-york-workforce-stay-home/index.html (accessed on 20 March 2020).

[61] U.S. News. Cuomo Extends Lockdown, Expands Mask Requirement. Available online: https://www.usnews.com/news/national-news/articles/2020-04-16/gov-andrew-cuomo-extends-ne w-york-lockdown-expands-mask-requirement (accessed on 16 April 2020).

[62] The Local. Norway extends coronavirus lockdown until after Easter. Available online: 
https://www.thelocal.no/20200324/norway-extends-coronavirus-lockdown-until-after-easter (accessed on 24 March 2020).

[63] YONHAP News Agency. Mun Jae-in: "Blockade " is only to stop the epidemic, not to "seal the city". Available online: https://cn.yna.co.kr/view/ACK20200225003200881 (accessed on 25 February 2020).

[64] Russian News Agency. Russia imposes entry ban for foreigners from March 18 to May 1 over coronavirus risks. Available online:

https://tass.com/society/1130915 (accessed on 17 March 2020).

[65] The Straits Times. Coronavirus: All short-term visitors barred from entering and transiting in Singapore from Monday, 11.59pm. Available online:

https://www.straitstimes.com/singapore/health/coronavirus-all-short-term-visitors-barred-from-ent ering-and-transiting-in (accessed on 22 March 2020).

[66] The Straits Times. Covid-19 circuit breaker to be extended by one month to June 1: PM Lee. Available online:

https://www.straitstimes.com/politics/prime-minister-lee-hsien-loong-to-address-nation-on-covid19-situation-at-5pm (accessed on 21 April 2020).

[67] The Guardian. South Africa to go into 21-day lockdown on Thursday night. Available online: https://www.theguardian.com/world/2020/mar/23/south-africa-to-go-into-21-day-lockdown-on-thu rsday-night (accessed on 23 March 2020).

[68] BusinessTech. South Africa's coronavirus lockdown extended by 2 weeks. Available online: https://businesstech.co.za/news/government/388743/south-africas-coronavirus-lockdown-extended -by-2-weeks/ (accessed on 9 April 2020).

[69] ELMUNDO (in Spanish). Pedro Sánchez anuncia el estado de alarma para frenar el coronavirus 24 horas antes de aprobarlo. Available online: https://www.elmundo.es/espana/2020/03/13/5e6b844e21efa0dd258b45a5.html (accessed on 13 March 2020).

[70] Bloomberg.com. Spain Extends Lockdown as Virus Cases Rise Again in Europe. Available online:

https://www.bloomberg.com/news/articles/2020-04-22/spain-extends-lockdown-as-virus-cases-ris e-again-in-europe (accessed on 23 April 2020).

[71] Finanz und Wirtschaft (in German). Bundesrat riegelt Schweiz ab-Truppen mobilisiert. Available online:

https://www.fuw.ch/article/bundesrat-ruft-den-notstand-aus/ (accessed on 16 March 2020)

[72] The Guardian. Boris Johnson orders UK lockdown to be enforced by police. Available online: https://www.theguardian.com/world/2020/mar/23/boris-johnson-orders-uk-lockdown-to-be-enforc ed-by-police (accessed on 23 March 2020).

[73] The Central People's Government of the People's Republic of China (in Chinese).

Announcement of the New Coronavirus-Infected Pneumonia Prevention and Control in Wuhan. Available online: http://www.gov.cn/xinwen/2020-01/23/content_5471751.htm (accessed on 23 January 2020). [74] The Central People's Government of the People's Republic of China (in Chinese). Wuhan: the channel of "unsealing" does not mean the release of epidemic prevention. Available online: http://www.gov.cn/xinwen/2020-04/07/content_5500019.htm (accessed on 7 April 2020). 


\section{Table Captions}

Table 1 -Parameter definition for COVID-19 model (1).

Table 2 -The basic reproduction numbers and growth ratios of cumulative confirmed cases.

\section{Figure Captions}

Figure 1 - Flow chart of compartments of the COVID-19 SEIQR model.

Figure 2 - The comparison between cumulative confirmed cases and the fitting results in 22 countries and cities.

Table 1. Parameter definition for COVID-19 model (1).

\begin{tabular}{lll}
\hline Parameter and intervals & Definition & Source \\
\hline \hline$\beta \in[0.01,10]$ & Transmission rate & Estimated \\
$\alpha$ & Transition rate of exposed & {$[4]$} \\
$\gamma \in[0.01,10]$ & Recovery rate & Estimated \\
$\omega \in[0.0667,0.2]$ & Detection rate & Estimated \\
$p \in[0.1,0.5]$ & Infectivity reduction factors & Estimated \\
$q \in[0.1,0.5]$ & Infectivity reduction factors & Estimated \\
$\rho \in[0.1,1]$ & & Proportion of the infectious \\
\end{tabular}




$\begin{array}{lll}\sigma \in[0.001,0.5] & \text { Removal rate } & \text { Estimated } \\ d \in[0.0001,0.05] & \text { Disease-induced death rate } & \text { Estimated }\end{array}$

Table 2 The basic reproduction numbers and growth ratios of cumulative confirmed cases.

\begin{tabular}{ccccc}
\hline & $\begin{array}{c}R_{0}{ }^{(1)}(\text { Before } \\
\text { Lockdown })\end{array}$ & $\begin{array}{c}R_{0}{ }^{(2)} \text { (After } \\
\text { Lockdown) }\end{array}$ & Average $\bar{R}_{0}$ & Growth ratio $\Delta$ \\
\hline Australia & 4.0336 & 1.2201 & 1.8532 & 1.0482 \\
Belgium & 4.1926 & 1.5326 & 2.1976 & 2.4554 \\
California, America & 2.3109 & 1.2227 & 1.5191 & 1.4246 \\
Canada & 2.5957 & 1.5197 & 1.8111 & 1.6237 \\
Denmark & 1.3884 & 1.2241 & 1.2561 & 0.4243 \\
Egypt & 2.8205 & 1.2320 & 1.6384 & 0.7849 \\
France & 3.1366 & 2.4195 & 2.6490 & 1.3711 \\
Germany & 3.9865 & 1.2143 & 2.3786 & 1.9993 \\
Illinois, America & 3.9761 & 1.3158 & 1.8059 & 5.5938 \\
India & 2.7518 & 1.2219 & 1.6471 & 1.2256 \\
Italy & 3.7270 & 2.7392 & 3.0038 & 1.3875 \\
New Jersey, American & 3.3610 & 2.4150 & 2.5940 & 4.0000 \\
New York, America & 3.9682 & 3.0673 & 3.3187 & 4.6955 \\
Norway & 3.9850 & 1.4671 & 2.4399 & 1.4513 \\
Republic of Korea & 3.6281 & 1.2234 & 1.5286 & 7.0096 \\
Russian Federation & 3.9190 & 3.7829 & 3.8067 & 1.7353 \\
Singapore & 3.6653 & 1.5866 & 2.5012 & 0.4607 \\
\hline
\end{tabular}




\begin{tabular}{cllll}
\hline South Africa & 3.9743 & 1.3025 & 2.1690 & 1.7024 \\
Spain & 4.1572 & 2.6451 & 3.0154 & 4.0340 \\
Switzerland & 3.9784 & 1.2231 & 1.9259 & 2.4109 \\
The United Kingdom & 3.0901 & 1.5332 & 2.2182 & 1.5681 \\
Wuhan, China & 3.0118 & 1.9860 & 2.1606 & 2.5124 \\
\hline
\end{tabular}

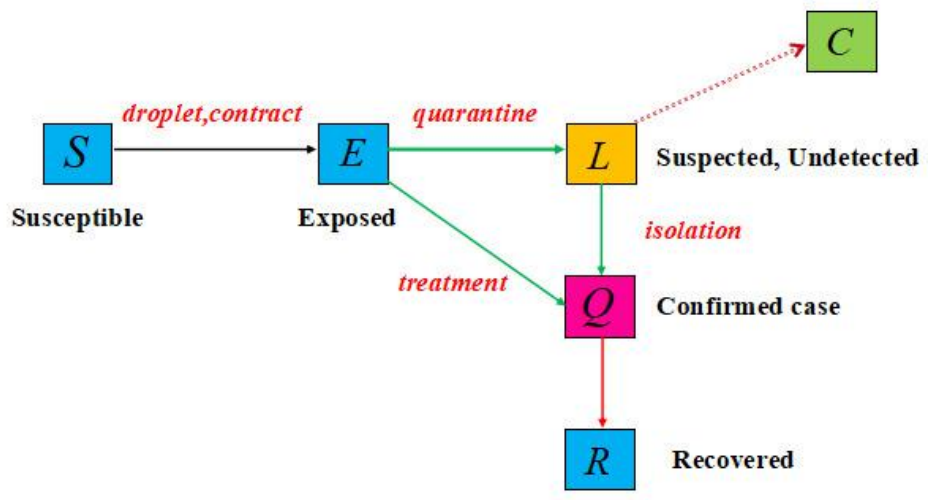

Fig1. Flow chart of compartments of the COVID-19 SEIQR model. 



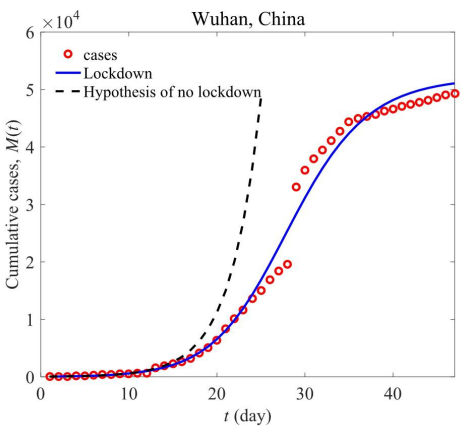

(a)

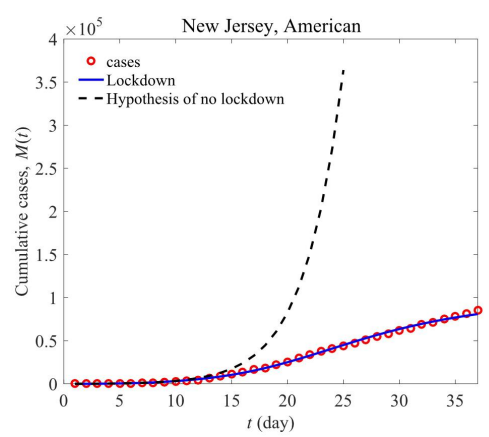

(d)

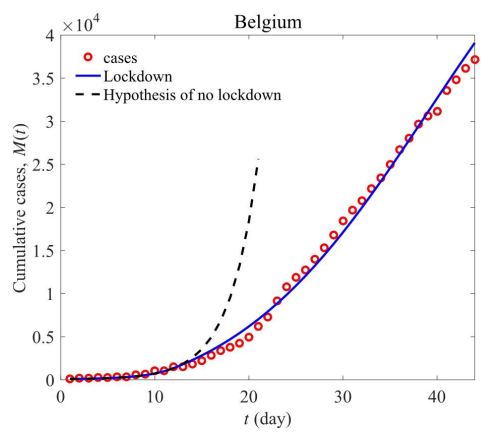

(g)

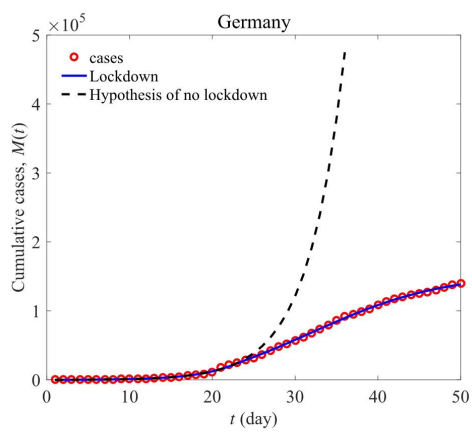

(j)

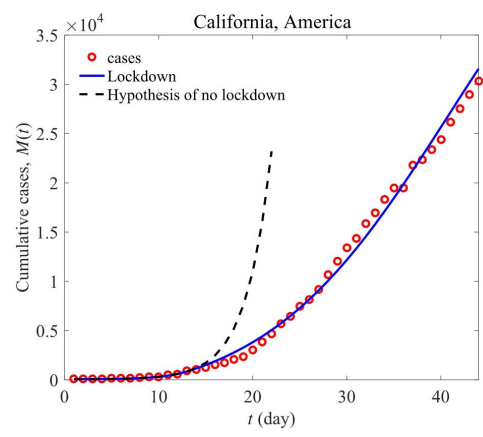

(b)

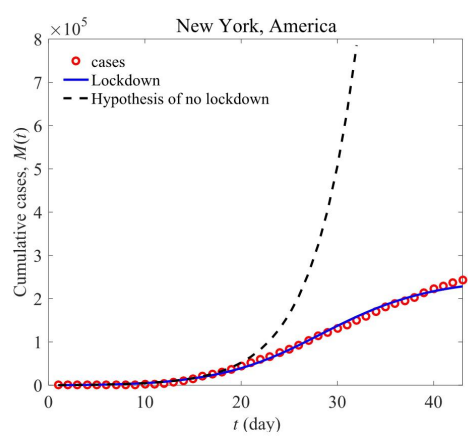

(e)

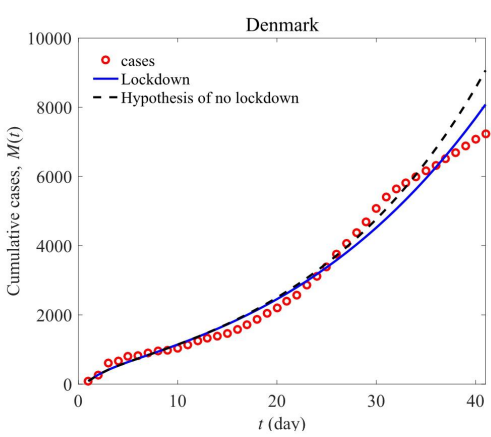

(h)

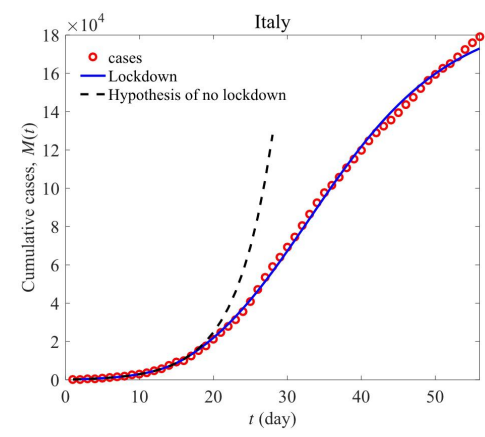

(k)

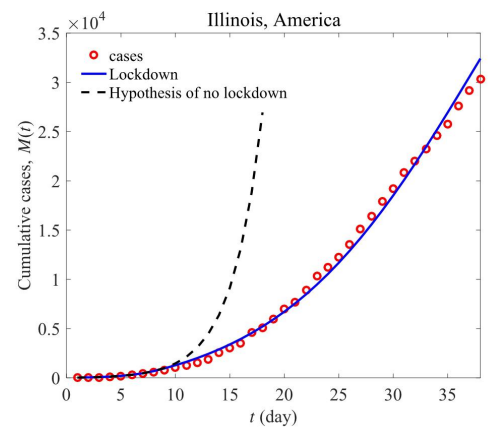

(c)

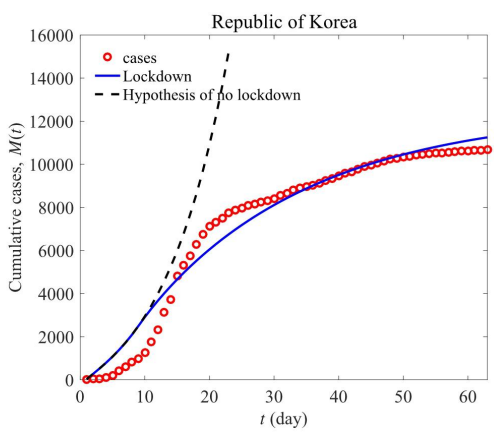

(f)

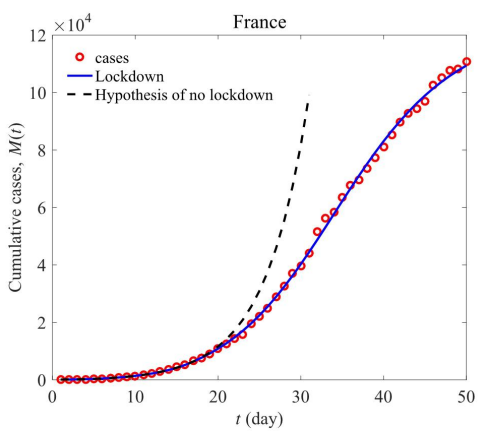

(i)

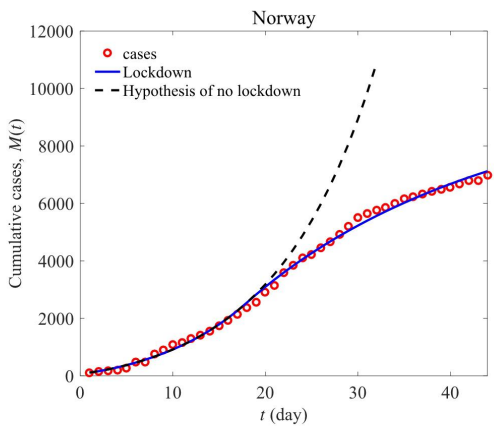

(1) 


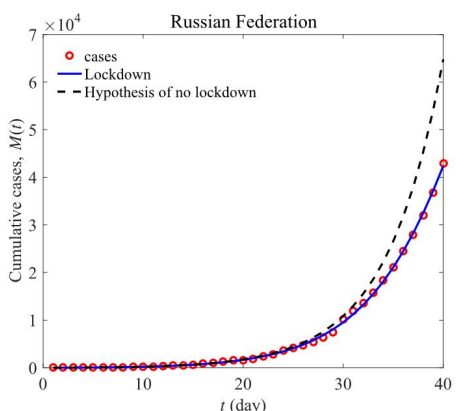

(m)

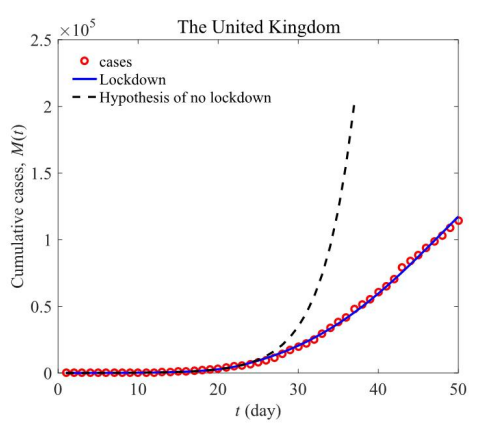

(p)

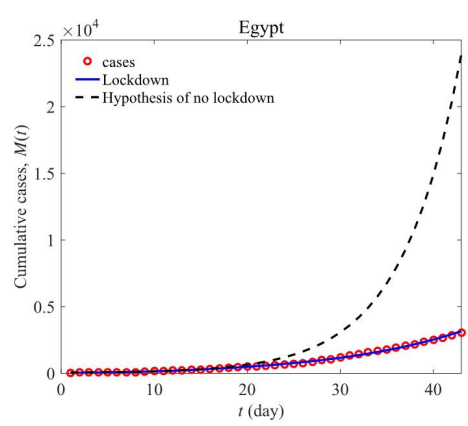

(s)

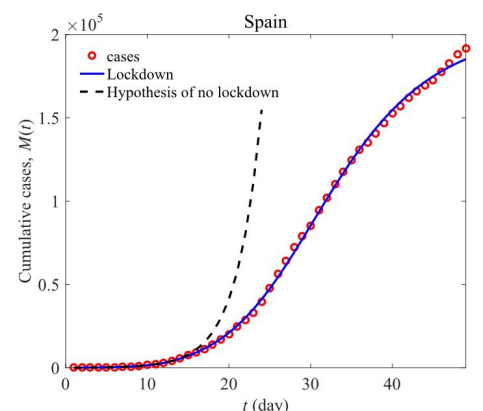

(n)

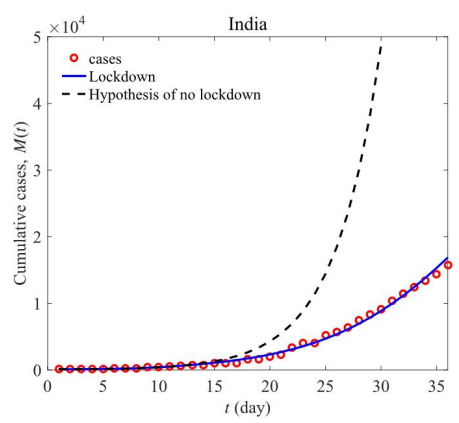

(q)

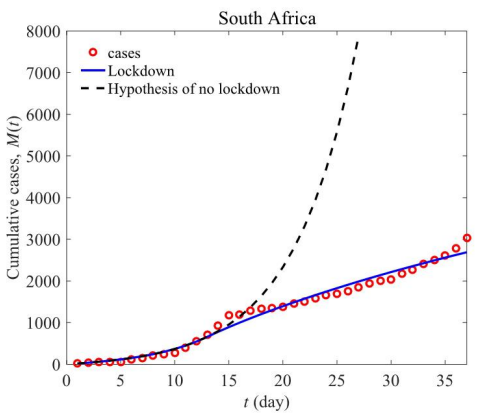

(t)

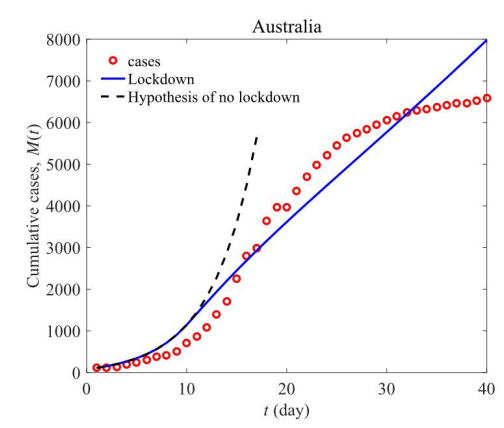

(v)

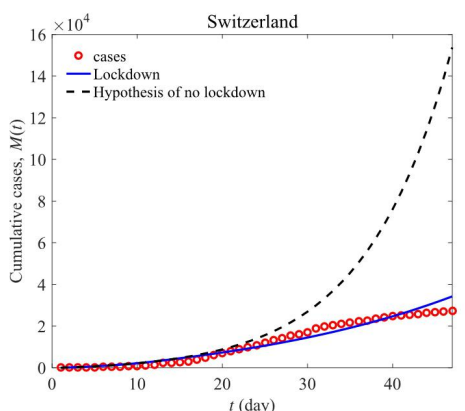

(o)

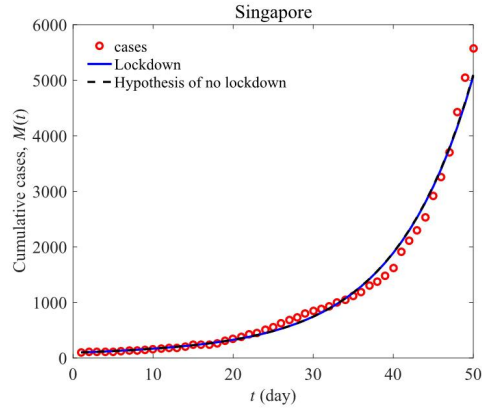

(r)

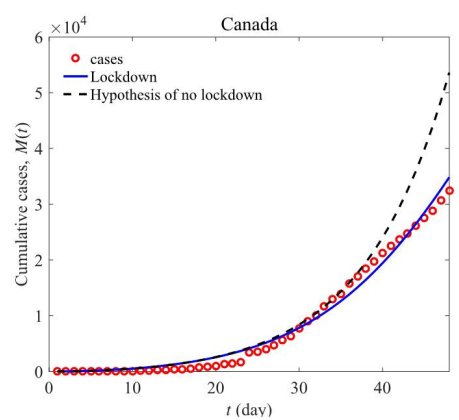

(u) 


\section{Supplementary Materials:}

Table 3. Overview on lockdown for the COVID-19 pandemic in the 22 countries or cities.

\begin{tabular}{|c|c|c|c|}
\hline $\begin{array}{c}\text { Countries and } \\
\text { cities }\end{array}$ & Specific measures & State data & End data \\
\hline Australia & $\begin{array}{l}\text { Australian refused the non-residents entering the country on } \\
20 \text { March. The government put forward social distancing } \\
\text { measures on } 21 \text { March. "Non-essential" services were closed } \\
\text { which covering people get together in the taverns or } \\
\text { hostelries. }\end{array}$ & $\begin{array}{l}\text { 2020-03-20, } \\
{[41]}\end{array}$ & \\
\hline Belgium & $\begin{array}{l}\text { The National Security Council determined to take actions to } \\
\text { response to the COVID-19 epidemic on } 17 \text { March. Some } \\
\text { measures about social distancing were taken on } 18 \text { March } \\
\text { until } 5 \text { April. "Non-essential" things like travel, gathering } \\
\text { were banned. }\end{array}$ & $\begin{array}{l}\text { 2020-03-18, } \\
{[42]}\end{array}$ & $\begin{array}{l}\text { 2020-04-19, } \\
{[43]}\end{array}$ \\
\hline $\begin{array}{l}\text { California, } \\
\text { America }\end{array}$ & $\begin{array}{l}\text { Sacramento County demanded residents to stay at home on } \\
19 \text { March. The instruction was upgraded to official order } \\
\text { with legal results. }\end{array}$ & $\begin{array}{l}\text { 2020-03-19, } \\
{[44]}\end{array}$ & $\begin{array}{l}\text { 2020-05-15, } \\
{[45]}\end{array}$ \\
\hline Canada & $\begin{array}{l}\text { Provinces and cities in Canada closed the school, daycare } \\
\text { and unimportant businesses. Gatherings were banned. } \\
\text { Entrance and border access were restricted. All } \\
\text { newly returned travelers must quarantine themselves for two } \\
\text { weeks by the federal Minister of Health. }\end{array}$ & $\begin{array}{l}\text { 2020-03-16, } \\
{[46]}\end{array}$ & \\
\hline Denmark & $\begin{array}{l}\text { Some further active restrictions appeared at } 10: 00 \text { on } 18 \\
\text { March. No more than ten people are allowed to be together. } \\
\text { Restaurants did not permitted eat-in. The other shops in } \\
\text { business should provide enough space to prevent close } \\
\text { contact. }\end{array}$ & $\begin{array}{l}\text { 2020-03-18, } \\
{[47]}\end{array}$ & \\
\hline Egypt & $\begin{array}{l}\text { The Egyptian government decided to take measures to } \\
\text { restrict resident's activity from } 19 \text { to } 31 \text { March } 2020 \text {, namely, } \\
\text { all public areas all over the country were closed including } \\
\text { restaurants, cafes and nightclubs from } 7 \text { p.m. to 6a.m. the } \\
\text { next day. }\end{array}$ & $\begin{array}{l}\text { 2020-03-19, } \\
{[48]}\end{array}$ & \\
\hline France & $\begin{array}{l}\text { All the "Non-essential" places in public weren't allowed to } \\
\text { open at midnight under the prime minister's order which } \\
\text { obtain cinemas, restaurants, nightclubs and restaurants. }\end{array}$ & $\begin{array}{l}\text { 2020-03-17, } \\
{[49]}\end{array}$ & $\begin{array}{l}\text { 2020-05-11, } \\
{[50]}\end{array}$ \\
\hline Germany & $\begin{array}{l}\text { The government issued a nationwide curfew to keep } \\
\text { residents staying at home except some certain activities. } \\
\text { People could hitchhike to work. They were able to exercise } \\
\text { themselves and made purchases. However more than two } \\
\text { people were not allowed unless they came from the same } \\
\text { family. }\end{array}$ & $\begin{array}{l}\text { 2020-03-23, } \\
{[51]}\end{array}$ & $\begin{array}{l}\text { 2020-05-03, } \\
{[52]}\end{array}$ \\
\hline Illinois, America & Measures were taken to control the virus's spread by the & 2020-03-20, & 2020-05-30, \\
\hline
\end{tabular}




\begin{tabular}{|c|c|c|c|}
\hline & $\begin{array}{l}\text { method of closing schools, asking the restaurants and bars to } \\
\text { provide packaged food, ordering a stop to eviction } \\
\text { enforcements. People's gatherings were restricted. }\end{array}$ & {$[53]$} & {$[54]$} \\
\hline India & $\begin{array}{l}\text { Modi declared that the country will implement lockdown } \\
\text { policy which lasts } 21 \text { days on } 24 \text { March } 2020 \text {. About } 1.4 \\
\text { billion people's movement would be influenced. }\end{array}$ & $\begin{array}{l}\text { 2020-03-25, } \\
{[55]}\end{array}$ & $\begin{array}{l}\text { 2020-05-03, } \\
{[56]}\end{array}$ \\
\hline Italy & $\begin{array}{l}\text { In Italy, the whole events on sports would be banned until at } \\
\text { least to April } 3^{\text {rd }} \text { according to the government's } \\
\text { announcement. Conte gave an announcement that previous } \\
\text { lockdown measures were extended from "red zones" to the } \\
\text { whole country in the evening which leading about } 60 \text { million } \\
\text { people couldn't go out the country. And he signed the new } \\
\text { executive order in official recognition later. }\end{array}$ & $\begin{array}{l}\text { 2020-03-09, } \\
{[57]}\end{array}$ & $\begin{array}{l}\text { 2020-05-03, } \\
{[58]}\end{array}$ \\
\hline $\begin{array}{c}\text { New Jersey, } \\
\text { American }\end{array}$ & $\begin{array}{l}\text { Governorn Murphy made an announcement which asks all } \\
\text { state residents to stay at home that the whole non-essential } \\
\text { businesses would face the closure by } 9 \mathrm{p} . \mathrm{m} \text {. on } 21 \text { March. }\end{array}$ & $\begin{array}{l}\text { 2020-03-21, } \\
{[59]}\end{array}$ & \\
\hline $\begin{array}{l}\text { New York, } \\
\text { America }\end{array}$ & $\begin{array}{l}\text { Blasio appealed to have a shelter-in-place model like } \\
\text { California on } 20 \text { March. Cuomo declared that people should } \\
\text { stay at home. }\end{array}$ & $\begin{array}{l}\text { 2020-03-20, } \\
{[60]}\end{array}$ & $\begin{array}{l}2020-05-15, \\
{[61]}\end{array}$ \\
\hline Norway & $\begin{array}{l}\text { The lockdown measures were put forward and would take } \\
\text { effect at } 6 \mathrm{p} . \mathrm{m} \text {. on } 12 \text { March. Everything related to gatherings } \\
\text { would be banned to open or cancelled, like schools, centers, } \\
\text { restaurants, cultural events, sports and so on. }\end{array}$ & $\begin{array}{l}\text { 2020-03-12, } \\
{[62]}\end{array}$ & $\begin{array}{l}\text { 2020-04-13, } \\
{[62]}\end{array}$ \\
\hline $\begin{array}{c}\text { Republic of } \\
\text { Korea }\end{array}$ & $\begin{array}{l}\text { Korean government took measures to protect nationals like } \\
\text { sealing off the city to the maximum extend to control the } \\
\text { outbreak in Daegu and Gyeongsangbuk-do. }\end{array}$ & $\begin{array}{l}\text { 2020-02-25, } \\
{[63]}\end{array}$ & \\
\hline $\begin{array}{c}\text { Russian } \\
\text { Federation }\end{array}$ & $\begin{array}{l}\text { The government took actions to slow down the rate of } \\
\text { infection. Events were abolished. Entertainment venues like } \\
\text { theaters were closed. Borders were shut. And there was a } \\
\text { declared non-working period appeared till } 30 \text { April. }\end{array}$ & $\begin{array}{l}\text { 2020-03-18, } \\
{[64]}\end{array}$ & $\begin{array}{l}\text { 2020-05-01, } \\
{[64]}\end{array}$ \\
\hline Singapore & $\begin{array}{l}\text { All travellers whether or not local residents came to } \\
\text { Singapore must submit health claim online before going } \\
\text { through immigration at 9a.m. from } 27 \text { March under the } \\
\text { Immigration and Checkpoints Authority's announcement. }\end{array}$ & $\begin{array}{l}\text { 2020-03-27, } \\
{[65]}\end{array}$ & $\begin{array}{l}\text { 2020-06-01, } \\
{[66]}\end{array}$ \\
\hline South Africa & $\begin{array}{l}\text { No gatherings except funerals such as restaurants, hotels, } \\
\text { bars were allowed in the lockdown period. Only shops that } \\
\text { selling essential goods were permitted to open. }\end{array}$ & $\begin{array}{l}\text { 2020-03-26, } \\
{[67]}\end{array}$ & $\begin{array}{l}\text { 2020-04-30, } \\
{[68]}\end{array}$ \\
\hline Spain & $\begin{array}{l}\text { Some compulsive lockdown requirements were carried out } \\
\text { including only people who are going to buy food or } \\
\text { medicines and that need to work or attend pressing matter } \\
\text { can leave their home, non-essential businesses like cinemas } \\
\text { and retail will be closed. }\end{array}$ & $\begin{array}{l}\text { 2020-03-14, } \\
{[69]}\end{array}$ & $\begin{array}{l}\text { 2020-05-09, } \\
{[70]}\end{array}$ \\
\hline Switzerland & $\begin{array}{l}\text { Further measures were put forward by the Immigration and } \\
\text { Checkpoints Authority which asked the gathering public }\end{array}$ & $\begin{array}{l}\text { 2020-03-17, } \\
{[71]}\end{array}$ & \\
\hline
\end{tabular}




\begin{tabular}{|c|c|c|c|}
\hline & $\begin{array}{l}\text { places including shops and bars to close until } 19 \text { April on } 16 \\
\text { March 2020. A number of essential businesses obtaining } \\
\text { postal service, drugstore, goods store and public transport } \\
\text { could able to operate to leave. }\end{array}$ & & \\
\hline $\begin{array}{l}\text { The United } \\
\text { Kingdom }\end{array}$ & $\begin{array}{l}\text { Lockdown measures were imposed by the government on } \\
\text { everyone on } 23 \text { March. People contacting with others could } \\
\text { only in their home and they couldn't go outside because of } \\
\text { "Non-essential" travel and almost everywhere were ordered } \\
\text { to shut down, such as venues, places to pray and facilities. }\end{array}$ & $\begin{array}{l}\text { 2020-03-23, } \\
{[72]}\end{array}$ & \\
\hline Wuhan, China & $\begin{array}{l}\text { The city's bus, subway, ferry, long-distance passenger } \\
\text { transport suspended operations since 10a.m. on } 23 \text { January. } \\
\text { Citizens were not allowed to leave Wuhan except for special } \\
\text { reasons. Airports and train stations were temporarily closed. }\end{array}$ & $\begin{array}{l}\text { 2020-01-23, } \\
{[73]}\end{array}$ & $\begin{array}{l}\text { 2020-04-08, } \\
{[74]}\end{array}$ \\
\hline
\end{tabular}


Table 4. Parameter values of 22 countries or regions (Before lockdown, $\beta_{1}$ and $\rho_{1}$; after lockdown, $\beta_{2}$ and $\rho_{2}$.

\begin{tabular}{|c|c|c|c|c|c|}
\hline Parameters & Australia & Belgium & California, America & Canada & Denmark \\
\hline $\mathrm{S}(0)$ & 25550560 & 11527642 & 39770000 & 37625816 & 5835857 \\
\hline $\mathrm{E}(0)$ & 189.5838328 & 25.43058263 & 314.54874443 & 10 & 11.35749731 \\
\hline $\mathrm{I}(0)$ & 23.17552933 & 22.81366263 & 31.914129114 & 148.7127856 & 422.4645119 \\
\hline $\mathrm{Q}(0)$ & 0.09185999 & 24.90225402 & 220.72589173 & $1.94 \mathrm{E}-08$ & 0.014624127 \\
\hline $\mathrm{R}(0)$ & 3.811730397 & 64.76607357 & 720.01668138 & 11.82201047 & 1.089858989 \\
\hline $\mathrm{M}(0)$ & 112 & 109 & 69 & 27 & 90 \\
\hline $\mathrm{D}(0)$ & $1.51 \mathrm{E}-07$ & 6.769032727 & 71.245035813 & 3.779649521 & 0.947282383 \\
\hline $\mathrm{S}\left(\mathrm{t}^{*}\right)$ & 8507625.774 & 100000 & 100007.4313 & 122706.1409 & 100001.3415 \\
\hline$\alpha$ & 0.196078431 & 0.196078431 & 10.196078431 & 0.196078431 & 0.196078431 \\
\hline$\beta_{1}$ & 1.289765911 & 1.312948649 & 91.421683387 & 0.263786969 & 0.332458549 \\
\hline $\mathrm{d}$ & 0.043246949 & 0.162404836 & 60.199992157 & 0.168530171 & 0.097456422 \\
\hline$\gamma$ & 0.08661704 & 0.001220649 & 90.099996243 & 0.000181546 & 0.068271145 \\
\hline$\sigma$ & 0.5 & 0.327293962 & 20.455763901 & 0.002235696 & 0.5 \\
\hline$\omega$ & 0.155488683 & 0.214998226 & 60.290682687 & 0.131829023 & 0.089769315 \\
\hline $\mathrm{p}$ & 0.100229888 & 0.122351347 & 70.100000001 & 0.999762174 & 0.709030711 \\
\hline$q$ & 0.499999971 & 0.43550978 & 0.34108774 & 0.105268901 & 0.129793802 \\
\hline$\rho_{1}$ & 0.796198777 & 0.177812866 & 60.13703614 & 0.700405148 & 0.539672402 \\
\hline$\beta_{2}$ & 0.298922985 & 0.48275261 & 0.606135774 & 0.259222559 & 0.309114573 \\
\hline$\rho_{2}$ & 0.120006991 & 0.100000093 & 30.742751189 & 0.1664294 & 0.33019475 \\
\hline
\end{tabular}

\begin{tabular}{|c|c|c|c|c|c|}
\hline Parameters & Egypt & France & Germany & $\begin{array}{l}\text { Illinois, } \\
\text { America }\end{array}$ & India \\
\hline $\mathrm{S}(0)$ & 101967503 & 67399310 & 82702105 & 12760000 & 1377446025 \\
\hline $\mathrm{E}(0)$ & 10.11041698 & 10 & 11.49124314 & 81.8980581 & 12.34110474 \\
\hline $\mathrm{I}(0)$ & 18.32423686 & \multicolumn{2}{|c|}{192.7214487177 .0652049} & 19.09496945 & 58.3457049 \\
\hline $\mathrm{Q}(0)$ & 0.861644153 & \multicolumn{2}{|c|}{0.1293560070 .973561193} & 468.2077641 & 59.88767567 \\
\hline $\mathrm{R}(0)$ & 1.053005122 & \multicolumn{2}{|c|}{1.2012754151 .032121023} & 12.91430401 & 2.129158181 \\
\hline $\mathrm{M}(0)$ & 48 & 100 & 57 & 32 & 107 \\
\hline $\mathrm{D}(0)$ & 1.68357781 & $5.52 \mathrm{E}-16$ & 0.029537237 & 0.211615631 & 0.109626578 \\
\hline $\mathrm{S}\left(\mathrm{t}^{*}\right)$ & 100000.1454 & 149758.757 & 3131328.2821 & 100000.0009 & 100000 \\
\hline
\end{tabular}




\begin{tabular}{|c|c|c|c|c|}
\hline$\alpha$ & 0.196078431 & 0.1960784310 .196078431 & 0.196078431 & 0.196078431 \\
\hline$\beta_{1}$ & 0.528847074 & 0.7708979770 .491258426 & 0.989998109 & 0.467044727 \\
\hline d & 0.089062905 & $0.0487153981 .03 \mathrm{E}-06$ & 0.098220028 & 0.16538333 \\
\hline$\gamma$ & 0.029399084 & 0.0541489640 .067257567 & 0.078261458 & 0.099443091 \\
\hline$\sigma$ & 0.197103162 & 0.0182163190 .078617011 & 0.262390085 & 0.001000001 \\
\hline$\omega$ & 0.183465965 & 0.1470243860 .338708863 & 0.317732124 & 0.319623848 \\
\hline $\mathrm{p}$ & 0.26845327 & 0.1000009620 .66769323 & 0.27980713 & 0.686507341 \\
\hline$q$ & 0.499326727 & 0.3143229850 .296828248 & 0.5 & 0.499920758 \\
\hline$\rho_{1}$ & 0.1 & 0.1072671620 .658768906 & 0.144349768 & 0.404168782 \\
\hline$\beta_{2}$ & 0.230952498 & 0.6007892280 .161823355 & 0.324205485 & 0.216601104 \\
\hline$\rho_{2}$ & 0.102498812 & 0.1000001050 .268303473 & 0.240315407 & 0.324159222 \\
\hline
\end{tabular}

\begin{tabular}{|c|c|c|c|c|c|}
\hline Parameters & Italy & $\begin{array}{l}\text { New Jersey, } \\
\text { American }\end{array}$ & New York,America & Norway & $\begin{array}{l}\text { Republic of } \\
\text { Korea }\end{array}$ \\
\hline $\mathrm{S}(0)$ & 60266946 & 9030000 & 19795791 & 5412020 & 82012000 \\
\hline $\mathrm{E}(0)$ & 632.0539373 & 10.25900543 & 603.7223509 & 107.2351786 & 1242.16368 \\
\hline $\mathrm{I}(0)$ & 13.25841926 & 270.7858179 & 294.4368834 & 57.76218031 & 3.155437977 \\
\hline $\mathrm{Q}(0)$ & $1.95 \mathrm{E}-05$ & 45.88232527 & $3.47 \mathrm{E}-09$ & 448.1175846 & 1.178771074 \\
\hline $\mathrm{R}(0)$ & 416.7113522 & 3.102344953 & 1.121272002 & 2.630441637 & 94.66707165 \\
\hline $\mathrm{M}(0)$ & 229 & 50 & 105 & 113 & 31 \\
\hline $\mathrm{D}(0)$ & 0.016495808 & 0.754341253 & 1.89E-09 & 0.602191265 & 0.033708319 \\
\hline $\mathrm{S}(\mathrm{t} *)$ & 243180.418 & 107144.3889 & 265134.6242 & 4919125.968 & 5444047.079 \\
\hline$\alpha$ & 0.196078431 & 0.196078431 & 0.196078431 & 0.196078431 & 0.196078431 \\
\hline$\beta_{1}$ & 0.904704016 & 0.587748539 & 0.62399461 & 1.608175383 & 1.703029345 \\
\hline d & 0.097290077 & 0.050473046 & $1.03 \mathrm{E}-06$ & 0.199995328 & 0.190827174 \\
\hline$\gamma$ & 0.013878196 & 0.014511961 & 0.063260489 & 0.049768744 & 0.069654076 \\
\hline$\sigma$ & 0.5 & 0.049117063 & 0.001 & 0.351141107 & 0.307900843 \\
\hline$\omega$ & 0.23322937 & 0.495010283 & 0.277020079 & 0.08862127 & 0.0667 \\
\hline $\mathrm{p}$ & 0.118290686 & 0.1 & 0.835615797 & 0.1 & 0.153642482 \\
\hline q & 0.471707049 & 0.307831814 & 0.145879111 & 0.183382671 & 0.197480262 \\
\hline$\rho_{1}$ & 0.390133043 & 0.412300333 & 0.198116841 & 0.796199909 & 0.370267213 \\
\hline$\beta_{2}$ & 0.634522184 & 0.413478856 & 0.468103023 & 0.658773352 & 0.573050205 \\
\hline
\end{tabular}


\begin{tabular}{llllll}
\hline$\rho_{2}$ & 0.26113841 & 0.4990175610 .251944967 & 0.647491202 & 0.372256318
\end{tabular}

\begin{tabular}{|c|c|c|c|c|c|}
\hline Parameters & $\begin{array}{l}\text { Russian } \\
\text { Federation }\end{array}$ & Singapore & South Africa & Spain & Switzerland \\
\hline $\mathrm{S}(0)$ & 144249683 & 5760326 & 59167589 & 46712506 & 8629514 \\
\hline $\mathrm{E}(0)$ & 10.99506585 & \multicolumn{2}{|c|}{10.08120629120 .9386912} & 95.8470612 & 133.5077666 \\
\hline $\mathrm{I}(0)$ & 2.147078114 & \multicolumn{2}{|c|}{17.639594960 .875417232} & 45.13774192 & 272.4595353 \\
\hline $\mathrm{Q}(0)$ & 139.8554103 & $1.98 \mathrm{E}-09$ & $1.34 \mathrm{E}-13$ & 0.021367796 & 0.010081842 \\
\hline $\mathrm{R}(0)$ & 9.475726343 & \multicolumn{2}{|c|}{1.0009684921 .067823551} & 87.66337792 & 1.080239941 \\
\hline $\mathrm{M}(0)$ & 7 & 102 & 17 & 45 & 37 \\
\hline $\mathrm{D}(0)$ & $8.13 \mathrm{E}-14$ & \multicolumn{2}{|c|}{$0.2748432221 .06 \mathrm{E}-05$} & 0.057053631 & $1.56 \mathrm{E}-07$ \\
\hline $\mathrm{S}(\mathrm{t} *)$ & 209226.839 & \multicolumn{2}{|c|}{3479782.744117699 .8792} & 217208.7133 & 4885493.266 \\
\hline$\alpha$ & 0.196078431 & \multicolumn{2}{|c|}{0.1960784310 .196078431} & 0.196078431 & 0.196078431 \\
\hline$\beta_{1}$ & 0.499468235 & \multicolumn{2}{|c|}{0.3950227141 .633652597} & 1.099860897 & 0.888408654 \\
\hline d & 0.02230606 & $1.72 \mathrm{E}-05$ & 0.153188952 & 0.090320305 & 0.19999719 \\
\hline$\gamma$ & 0.097763275 & \multicolumn{2}{|c|}{0.0996636310 .1} & 0.029570804 & 0.045477883 \\
\hline$\sigma$ & 0.227716296 & 0.05574958 & 0.225329208 & 0.133655139 & 0.170870079 \\
\hline$\omega$ & 0.132027184 & \multicolumn{2}{|c|}{0.0700622140 .0667} & 0.246977735 & 0.111175971 \\
\hline $\mathrm{p}$ & 0.916101898 & \multicolumn{2}{|c|}{0.5750862660 .229892324} & 0.100311196 & 0.933219169 \\
\hline$q$ & 0.5 & \multicolumn{2}{|c|}{0.1000837760 .292980405} & 0.387143839 & 0.1 \\
\hline$\rho_{1}$ & 0.12270645 & 0.7962 & 0.140646173 & 0.1 & 0.102431642 \\
\hline$\beta_{2}$ & 0.478318419 & 0.391299889 & 0.31828144 & 0.646774264 & 0.270740773 \\
\hline$\rho_{2}$ & 0.557500615 & 0.1 & 0.796199999 & 0.307601971 & 0.113409041 \\
\hline
\end{tabular}

\begin{tabular}{|l|l|l|}
\hline Parameters & $\begin{array}{l}\text { The United } \\
\text { Kingdom }\end{array}$ & $\begin{array}{l}\text { Wuhan, } \\
\text { China }\end{array}$ \\
\hline $\mathrm{S}(0)$ & 67154714 & 11006500 \\
$\mathrm{y}(0)$ & 50.84726368 & 119.9614909 \\
$\mathrm{y}(0)$ & 0.55789758 & 31.88897219 \\
\hline $\mathrm{Q}(0)$ & 10.64059571 & 2.120220342 \\
\cline { 1 - 1 }$(0)$ & 1.000381623 & 79.54822742 \\
\cline { 1 - 1 }$(0)$ & 23 & 53 \\
\hline $\mathrm{D}(0)$ & 2.820549883 & $6.28 \mathrm{E}-09$ \\
\hline
\end{tabular}




\begin{tabular}{|c|c|c|}
\hline $\mathrm{S}\left(\mathrm{t}^{*}\right)$ & 292555.0779 & 100000.3412 \\
\hline$\alpha$ & 0.196078431 & 0.196078431 \\
\hline$\beta_{1}$ & 0.851205532 & 0.584902644 \\
\hline d & 0.178186469 & 0.186045425 \\
\hline$\gamma$ & 0.007412915 & 0.01086337 \\
\hline$\sigma$ & 0.219129133 & 0.001001504 \\
\hline$\omega$ & 0.201400814 & 0.269069912 \\
\hline $\mathrm{p}$ & 0.201211261 & 0.324810319 \\
\hline q & 0.5 & 0.5 \\
\hline$\rho_{1}$ & 0.134903393 & 0.354913022 \\
\hline$\beta_{2}$ & 0.368944752 & 0.456826862 \\
\hline$\rho_{2}$ & 0.674257344 & 0.137787625 \\
\hline
\end{tabular}


Figures

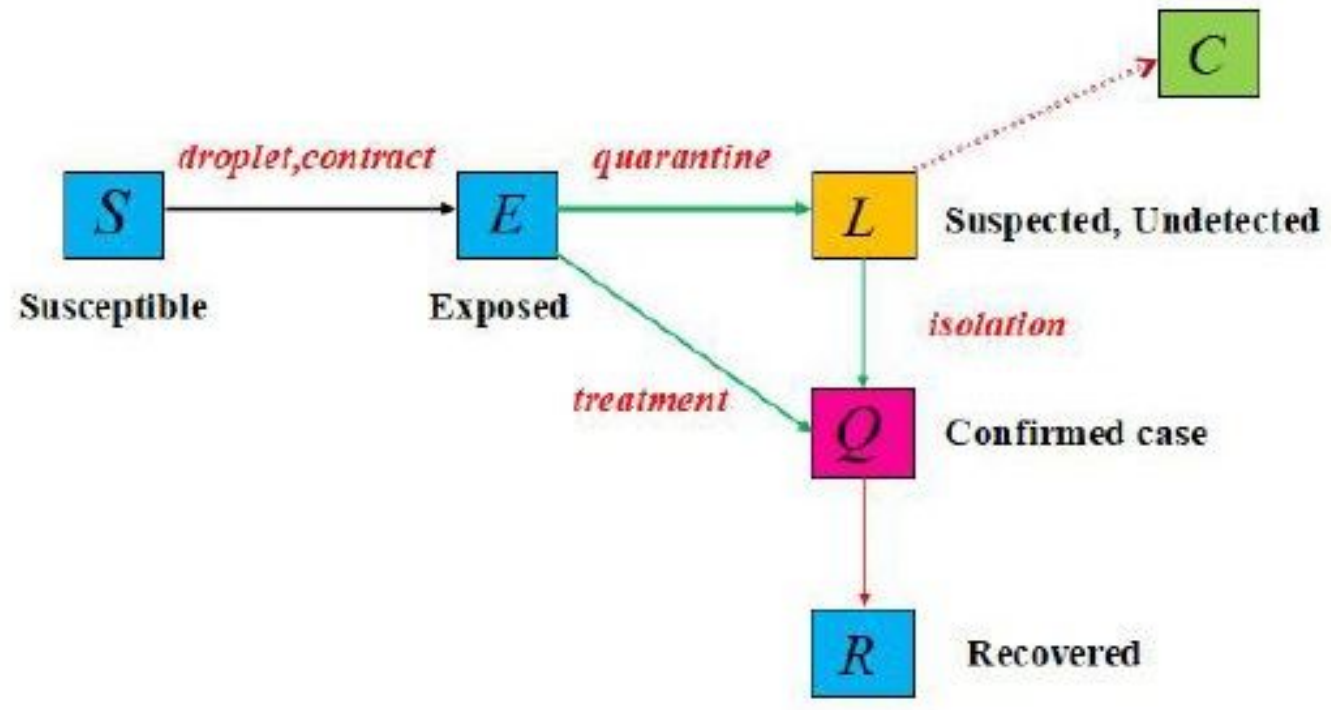

\section{Figure 1}

Flow chart of compartments of the COVID-19 SEIQR model.

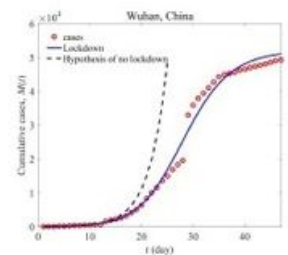

(a)
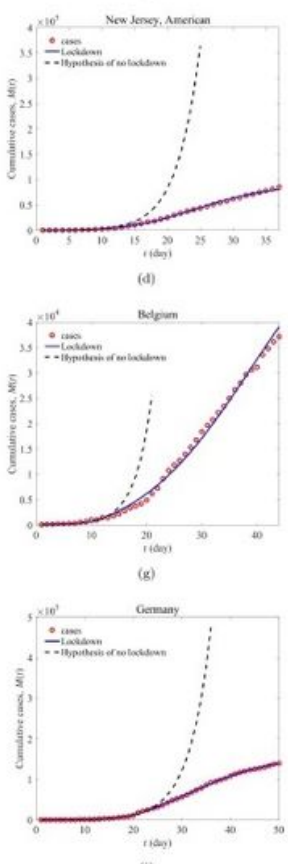
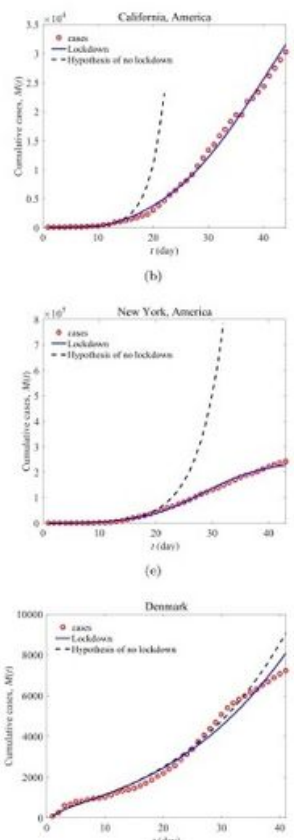

(b)

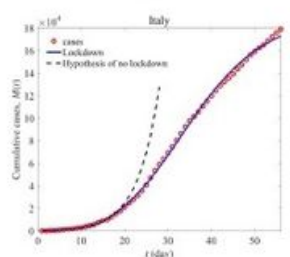

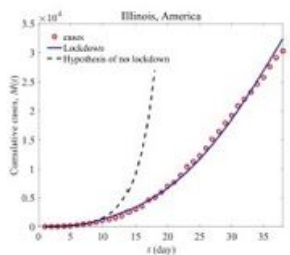
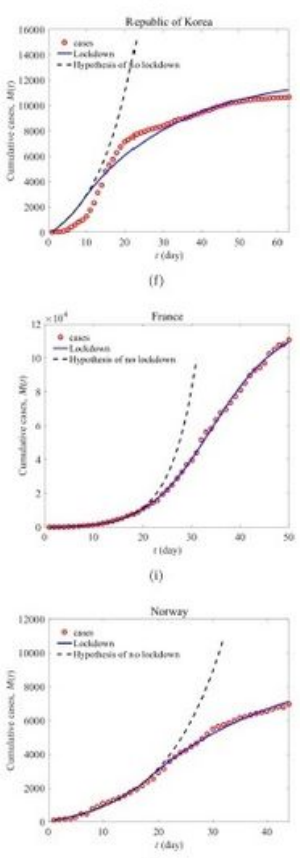
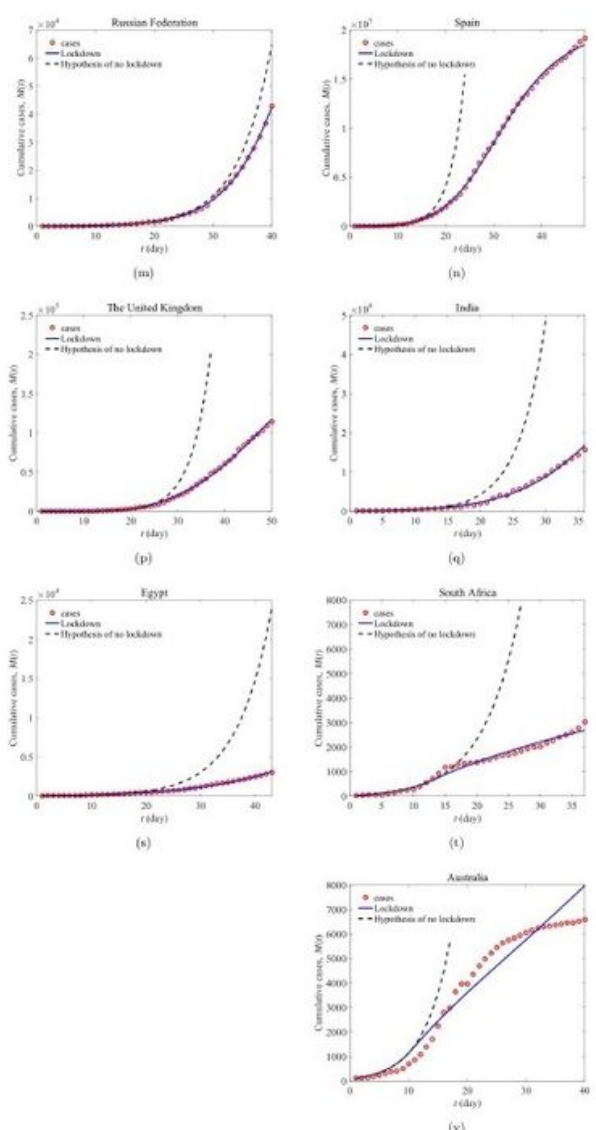
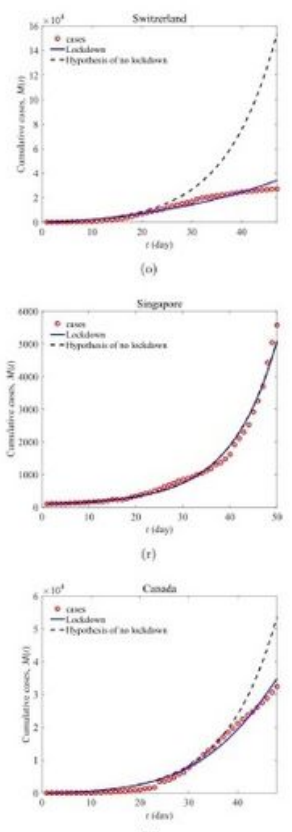

(a) 
Figure 2

The comparison between cumulative confirmed cases and the fitting results in 22 countries and cities 